\title{
https://doi.org/10.48009/2_iis_2009_309-315 \\ GETTING CONNECTED EVERYWHERE: BROADBAND POWER LINE TECHNOLOGY IN MEXICO
}

\author{
Guillermo Cesar, Texas A\&M University-Kingsville, gcesar55@aol.com \\ Joon-Yeoul Oh, Texas A\&M University-Kingsville, joon-yeoul.oh@tamuk.edu \\ HeeJoong Yang, Cheong Ju University, hjyang@cju.ac.kr
}

\begin{abstract}
Broadband Power Line technology can provide the various telecommunication services, such as internet, landline phone and IPTV with a low cost and wide coverage area by avoiding connection costs and using the existing power lines. Since the existing telecommunication service providers charge an expensive usage rate and the service covering area is concentrated on densely populated locations, some citizens in Mexico have no or incomparable telecommunication services. The broadband power line technology can be an alternative to provide the communication services in Mexico. This paper describes the broadband power line technology and the market needs on the telecommunication services. With over 28 million potential subscribers, the telecommunication market in Mexico has still an enormous potential to grow. The paper is concluded with concrete remarks based on the demand for the broadband power line technology.
\end{abstract}

Keywords: Broadband Power Line (BPL), BPL Technology, Internet Services, Cellular Telecommunications, VoIP, IPTV

\section{INTRODUCTION}

According to the Comisión Federal de Telecommunicaciones (COFETEL), Mexico's telecommunications regulating entity, the subscribers of the fixed lines and cellular phones are 20 Million fixed lines versus 71 Million cellular lines as of April 2008. Fixed line per minute rates range from USD $\$ 0.01$ to $\$ 0.28$ for local and long distance calls while cellular per minute rates range from $\$ 0.06$ - \$0.41 [1, 2]. Approximately 92 percent of cellular phone users utilize a prepaid billing plan rather than post pay system that is more common in the United States [3]. Average monthly rates for fixed lines users varies on the plan selected which is based on the amount of calls made under 5 minutes in duration. These average monthly rates range from USD $\$ 17.70$ for 100 calls to $\$ 73.70$ for 400 calls. Any overage of minutes on selected plans is billed per minute and the rate is determined by the region where the call is terminated [3]. Of the 20 million fixed lines in Mexico, only 3.1 million or 15.5 percent have ADSL capability or the ability to offer value added services such as high speed internet, making the other 84.5 percent of fixed phone lines obsolete allowing only traditional phone service [4].

\begin{tabular}{|l|c|}
\hline \multicolumn{2}{|c|}{ Key Facts and Numbers } \\
\hline \hline Local fixed line per minute rate & $\$ 0.01$ \\
\hline Long distance fixed line per minute rate & $\$ 0.28$ \\
\hline Local mobile line per minute rate & $\$ 0.06$ \\
\hline Long distance mobile line per minute rate & $\$ 0.41$ \\
\hline & $\$ 17.70$ \\
\hline Fixed Line Monthly Service Fee w/100 calls & $\$ 73.70$ \\
\hline Fixed Line Monthly Service Fee w/400 calls & $20,000,000$ \\
\hline & $71,000,000$ \\
\hline \# of fixed lines in service & $3,100,000$ \\
\hline \# of mobile lines in service & $16,900,000$ \\
\hline
\end{tabular}


Many countries including Mexico still have insufficient infrastructures and high priced usage charges for telecommunication services, such as internet, landline phone, cellular phones. According to the U.S. Commercial Service, the greatest opportunities for the telecommunications sector in Mexico for 2008 are in mobile applications, broadband applications, IPTV applications, VoIP applications and Powerline Communications [5]. The implementation of Broadband Powerline Network would satistfy consumer demand in the telecommunications sector throughout Mexico by providing a more advanced means of communication as well as a variety of value added services that require broadband rich applications while providing the greatest telecom opportunities presented by the U.S. Commercial Service in Mexico in 2008.

TelMex, created in 1947, is Mexico's fixed line incumbent. In 1972, TelMex became a government owned corporation before being partially privatized in 1990 when a $25 \%$ stake was sold to employees and the private sector [6]. It was not until 1996 that Mexico opened its domestic long distance and fixed line markets to competition and the government began granting licenses to local carriers in 1998 [6]. Since Mexico's deregulation of the telecommunications industry in 1998, Mexico has seen a great deal of investments in newer communications infrastructures such as fiber based networks and the highly penetrated cellular phone industry. While many citizens in areas of highly concentrated populations have some form of communication, most users are continually plagued by expensive per minute rates. However, others in rural areas have no access to communications as the adequate infrastructure is either not present or incompatible. Even though many multinational telecommunications corporations have entered the Mexico market, they cannot provide coverage to all areas because they have decided to deploy conventional infrastructures that are costly and very time consuming to deploy making it economically infeasible to operate in lowly population concentrated areas of the country. Thus, foreign market analysis is created as a means to highlight the potential of a BPL network in Mexico utilizing the current electric grid as a means to provide Broadband rich multimedia services.

This paper discusses about the broadband power line (BPL) communication network as an alternate to provide telecommunication services with low price and great coverage in Mexico. First of all, this paper describes the technology of BPL and the benefits when it is deployed. The next section discusses the applications and services with the BPL. The market size and target users for BPL services are also estimated, and the concluding remarks follow.

\section{BACKGROUND AND MARKET NEEDS}

The implementation of a Broadband Power Line/ Power Line Communications Network in Mexico would enable a service provider to use the existing power grid to enable broadband communications to all end users that have electricity in their home or place of business. Through the use of sophisticated technology, the network would incorporate smart grid applications to the current electrical grid as well as have the ability to offer package services including high speed internet, IPTV (Internet Protocol television), and VoIP (Voice over internet protocol) while addressing a very important socio-economic effects of connecting to the "last mile."

Broadband over Powel Lines (BPL) also known as Power Line Communication (PLC) is a system for sending and receiving radio signals over existing power lines to provide an alternative way to give internet services using an existing infrastructure. It operates using modulate carrier signals on different frequency bands while maintaining the initial use of providing power. These wires were not originally intended data transferring but it was found they can be used in this sense with little to no degradation of power [7].

Using the existing power grid, a BPL service provider will have the potential to provide various value added services to all current electricity subscribers in Mexico. Unlike a fiber network deployment where a curbside to home connection is needed, BPL utilizes the existing electrical wiring systems for a home or business using a conduit for its broadband connection. For example, Verizon spent $\$ 4,000$ per each customer to connect its home or business to the curbside connection in 2004. High subscription rates have decreased cost over time but still currently remain at $\$ 1,200$ to connect each customer's home or business [8]. By avoiding the connection cost between the curbside and home, BPL finds a great cost reduction compared to the providers that utilize fiber deployments.

The only thing needed on the consumer's side is a special BPL modem or CPE (consumer premise 
equipment) device connected to any existing electrical outlet. The setup is similar to a normal cable/DSL connection and the only requirement is that a subscriber has electricity in their home or place of business in order to access the internet [7].

This solution is ideal for less technologically advanced countries to access to the internet because it is not always feasible for the internet providers to deal with costs of laying cable and building an infrastructure in an area where they cannot generate as much profit as most urban areas [7]. Since there are still areas with little or no Internet connection, BPL is an emerging trend that is to connect many consumers with little more than electricity and devices.

\section{SERVICES OFFERED WITH BPL}

Providing 200 mega bits per second data rates, BPL can provide a low cost internet services compared to fiber, satellite and ADSL technology since there is no need to build infrastructure and it uses existing power grid. It would take only weeks to install the system to an entire city and undeveloped world. BPL services are already proven Eruopean technology and it has been used for several years throughout the world. The followings are the services provided by broadband over power lines.

\section{High Speed / Broadband Internet}

Once BPL is setup, it provides internet access wherever there is electricity. Since the internet provides a wealth of information at the user's fingertips which is really helpful for people that are isolated without adequate communications infrastructures, BPL technology is especially ideal for rural areas where the cost to provide any other form of connectivity is not feasible [7].

\section{VoIP}

Voice over internet protocol (VoIP) or internet telephony is an emerging trend to add voice to the existing internet protocol which allows the user to talk to others using the Internet instead of a traditional phone system [7]. VoIP provides many of the features of a traditional line including conference calling, forwarding, and caller ID which normally cost extra over traditional phone lines. In many cases, VoIP to VoIP calls are free whereas VoIP to land lines may have a little cost involved. It is also possible to make more secure calls with VoIP using a standardized secure protocol which works with the digital signal. VoIP also has been known to have better integration with other services especially on the web including video conversations, file transfers to callers, audio conferencing and most sharing information with each other [7].

\section{IPTV}

Internet protocol television (IPTV) provides digital television services using internet protocols instead of traditional coaxial cable. Since the Internet is usually bundles with other services, BPL can therefore work with other internet services. IPTV provides many different programs and movies with minimal cost because BPL companies are able to broadcast to a lot more customers than the cable companies do. IPTV also offers on demand viewing and interactivity with users making more convenient and personalized [9]. Some people may argue that IPTV is a luxury service but for some, it is the only way to get any type of television without an existing coaxial network, and thus the BPL service is the perfect solution.

\section{Smart Grid Applications}

A smart grid is another distribution network that uses two way communications, advanced sensors and distributed computers. The electric grid basically delivers electricity to consumers while the same electrical network also delivers information back from the consumers. Some of the features of this include self healing from power disturbances since these disturbances can be detected in real time. So, it is possible to start a chain of events to correct or redistribute power [10]. It is also able to continue operating in the event of a physical or cyber attack since it can act as its own entity which goes along with the fact that it can be self healing [10]. 


\section{MARKET SIZE ESTIMATION}

Services will be offered to two major channels that include residential and business consumers.

\section{Residential Customers}

According to Sistema de Informacion Energetic (SIE) in Mexico, there were 27,730,167 residential electricity subscriptions between CFE and Luz y Fuerza de Centro in May 2008. The figures can be potential residential market size for BPL services [11]. A BPL service provider will have the ability to offer various package services to its residential customers. Most of service providers have three types of packages, such as, premium, standard and basic. Each service plan provides a different data rate and/or service minutes allowed. To estimate the number of residential customers that has each package service, an electricity usage data can be used because the electricity usage usually depends on their incomes. If the temperature goes up high, most people will try to use their cooling equipments; otherwise, they will try not to use them except the people that can afford it.
Based on the monthly sales rates in 2008 provided by SIE, the sales was 25 percent of the month when the average temperature was between $77^{\circ} \mathrm{F}$ and $82.4^{\circ} \mathrm{F}$. The average temperature between $86^{\circ} \mathrm{F}$ and $87.8^{\circ} \mathrm{F}$ made up 60 percent of sales, and 15 percent of sales was made with the average temperature of over $89.6^{\circ} \mathrm{F}$. Thus, it can be assumed that about 25 percent of customers may purchase for the premium service plan. The remaining 60 and 15 percent of customers may purchase for the standard and basic service plan, respectively [11].

\section{Business Customers}

According to Sistema de Informacion Energetic in Mexico, as of May 2008 there were 3,768,831 commercial/services/agriculture/industrial electricity subscriptions [11]. Since the electricity usage for business will be correlated to the residential usage, the same percentages will be applied to the service plans for the business customers. Thus, the estimation would be 25 percent, 60 percent and 15 percent for the premium, standard and basic service plan, respectively.

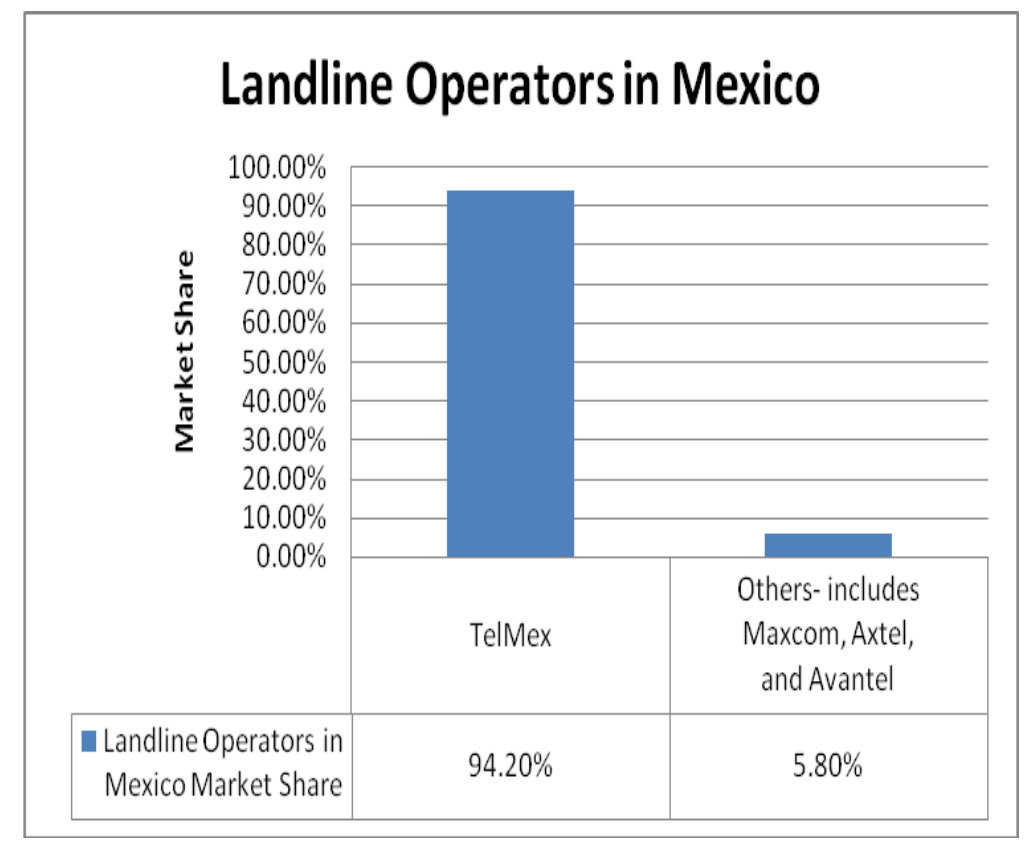

\section{TARGET USERS DESCRIPTION}

Currently, Mexico has one of the highest telecommunication use rates in Latin America with 64.2 for cellular phone users and 23.6 for internet users per 100 residents while fixed line penetration is at 18.6 out of 100 residents $[1,10,12]$. However, the discrepant amount between cellular users and fixed line telephone users indicates that the service providers have opted to introduce newer technologies 
that are more economically feasible option, such as GSM cellular systems in the area of concentrated population. It also indicates that if the adequate infrastructure for fixed line telephony is not present, then neither the infrastructure for cable TV nor high speed internet service. This analysis will focus on customers that have an electricity subscription, but do not have fixed line phone, internet and cable services.

\section{Electricity vs. Fixed Telephone Line End User Statistics}

Mexico currently has approximately 20 million fixed lines of which 93 percent are owned by Telmex [5]. However, approximately only 3.1 million out of the 20 million lines or 15.5 percent are ADSL compatible while the remaining 84.5 percent of lines are for only fixed line telephony service [6]. Since currently 3.1 million lines will be able to offer similar broadband rich services, such as IPTV, VoIP and high speed internet, the remaining about 16.9 millions will be the penetration that a BPL service provider can potentially provide services. According to the Sistema de Informacion Energetica, there are 31.8 million active subscribers of electricity [11]. This figure is essentially the market size that fully deployed BPL network can provide services because its services could be offered to all that have electricity subscriptions in their homes or places of business. Therefore, approximately 11.8 million more customers (31.8 electricity subscribers - 20 million fixed lines) that do not have fixed line access, because the infrastructure is not present or obsolete, will now have the necessary infrastructure that can have IPTV, VoIP, and high speed internet services without installing the additional wiring to their promises. Hence, once the BPL service is fully deployed, total potential market size becomes 28.7 million customers in Mexico.

\section{Electricity vs. Cellular Phone End Users Statistics}

Cellular telephones are by far the most highly penetrated form of communication in Mexico with over 71 million active cellular phones of which 92 percent of 71 million phones uses a prepay system [3]. This statistic is more than double the amount of electricity subscribers. It can be easily assumed that families share electricity under one subscription while each family member usually owns his or her own cell phone. We can assume that roughly 30 percent (correlated to fixed line statistics ratios or 3:1 ratio) of subscribers use cellular phone only because there is not an adequate infrastructure for fixed telephony. Since one user can have more than one subscription, the percentage that uses cellular phone only, because of the lack of the fixed line infrastructure, will go up. Some users may prefer lower fixed line per minute rates instead of expensive cell phone per minute rate if the option were available. Although the conveniences to use cellular phone play an integral part in the consumer's selection, price consideration in low income concentrated population areas is extremely important. Consequently, about 21 million cell phone subscribers would likely select a BPL service provider's product due to significant cost saving derived from reduced per minute rates.

\section{Electricity vs. Internet End Users Statistics}

According to COFETEL's 2007 report about the internet users' accessing location, there were only 22.8 million people accessed the internet and roughly 21.5 out of 100 internet users of which 7.8 million accessed it at home while the remaining 14.9 million users accessed the internet outside their home [13]. Of the 14.9 million users, only 5.35 million had computers at home and the remaining 9.6 million did not have a computer at home [13]. It can be assumed that the 5.35 million users have no internet service at home or the computer has no access to an adequate infrastructure.

This assumption is made based on the fact that they could afford a computer, so price would not partake in the decision as to whether or not they could afford the monthly internet fee imposed by the service provider. COFETEL also states that 1.8 people out of 100 had a broadband internet subscription [14]. Therefore, of the 7.8 million users that accessed the internet from their home only 1.4 million of them had broadband internet in their home. Therefore, a BPL service provider could offer its high speed internet services to 11.75 million internet users (5.35 million users without internet but with a computer plus 6.4 million users that have no broadband internet subscriptions) at home via its broadband network.

\section{Electricity vs. Cable TV End Users Statistics}

According to COFETEL 2007 report on the restricted TV penetration rate, only 61.1 people per 1000 have a cable subscription or roughly 4.3 million are cable TV subsribers, 1.4 million are satellite subscribers and 724,000 users have microwave singal cable [15, 16]. This analysis assumes that TV subscribers receive cable programming via satellite and microwave because they have no other infrastructure capability offered in their area. COFETEL states that, on average, 91 percent of households have a television in throughout Mexico [17]. Consequently, 
a BPL service provider would also be able to offer its IPTV services to these individuals that have a television but do not have a cable service subscription.

\section{CONCLUSIONS}

The broadband power line technology network may be a great alternative to provide the telecommunication services in Mexico and other less technologically advanced third world countries throughout Latin America. The concentration of traditional telecommunication infrastructures around major metropolitan areas has left many areas of the country with little or no form of communications infrastructure. This is due to the poverty level conditions that the services are economically infeasible for a company in many rural areas. However, many of these rural areas that do not have a communications infrastructure have access to electricity. This simple fact makes BPL an ideal choice to provide telecommunication services to the rural areas because no additional infrastructure is required. By simply adding BPL equipment such as head end units and couplers on the existing power lines, many of the rural areas could be connected to cyberspace and the rest of the world. A BPL network would not only increase telecommunications infrastructure capabilities in Mexico but it would also address a socio-economic effect that would stimulate the local economy and improve communication in the areas in which it is currently unavailable.

\section{REFERENCES}

1. Lineas Telefonicas en Servicio y Densidad Telefonica 1990-2008. (2008). Retrieved December 5, 2008, from http://

cofetel.gob.mx/wb/Cofetel_2008/Cofe_lineas_telefon icas_en_servicio_y_densidad_tel

2. Telefonia Movil Usuarios 1990-2007 Mensual. (2008). Retrieved December 5, 2008, from

http://cofetel.gob.mx/wb/Cofetel_2008/Cofe_telefoni a_movil_usuarios_1990_2007_mensual

3. Evolucion de las Tarifas Telefonicas en Mexico Annual. (2008). Retrieved December 5, 2008, from

http://cofetel.gob.mx/wb/Cofetel_2008/Cofe_evaluac ion_de_las_tarifas_telefonicas_en_mexi

4. Cuentas de Internet por tipo de Technologia 2000-2007. (2008). Retrieved December 5, 2008, from

http://cofetel.gob.mx/wb/Cofetel_2008/Cofe_cue ntas_de_internet_por_tipo_de_tecnologia_20
5. IT and Telecom in Mexico. (2008). US Commercial Service, Retrieved November 4, 2008, from

http://www.buyusa.gov/mexico/en/telecom.html\#_se ction 4

6. Telecoms. (2006). Latin American Monitor: Mexico Monitor, Retrieved December 5, 2008, from http://0-

search.ebscohost.com.oasis.lib.tamuk.edu/login.a spx?direct $=$ true $\& d b=b$ th $\& A N=21308832 \&$ site $=$ ehost -live

7. United Power Line Council. (2008). "What is Broadband over Powerlines?" Retrieved November 1, 2008, from http://www.uplc.org

8. Schley, S. (2006). Verizon Boost Fiber in its Network Diet. MultiChannel News, Retrieved November 4, 2008, from

http://www.multichannel.com.idex.asp?layout=article Print $\&$ articleID $=$ CA6388435

9. IT Insight. (2007). "What's the Hype about IPTV?" IT Insight, Retrieved November 1, 2008, from

http://www.itinsight.info/hypeaboutiptv.htm

10. Smart Grid. (2008). United States Department of Energy, Retrieved November 2, 2008, from

http://www.oe.energy.gov/smartgrid.htm

11. Lineas de Transmision. (2008). Retrieved December 5, 2008, from http://www.sie.energia.gob.mx

12. Comparativo Internacional de Penetracion de Suscitrores de Banda Ancha 2007. (2007). Retrieved December

5 ,

2008,

from http://cofetel.gob.mx/wb/Cofetel_2008/comparativo_ internacional_de_penetracion_de_susc07

13. Usarios de Internet en Mexico 2000-2008. (2009). Retrieved December 5, 2008, from

http://cofetel.gob.mx/wb/Cofetel_2008/Cofe_usuario s_estimados_de_internet_en_mexico_2000

14. Comparativo Internacional de Penetracion de Suscitrores de Internet de Banda Ancha 2005. (2005). Retrieved

December 5, 2008, from

http://cofetel.gob.mx/wb/Cofetel_2008/Cofe_compar ativo_internacional_de_penetracion_e_s

15. Television Restringida 1992-2008. (2008). Retrieved December 5, 2008, from

http://www.cft.gob.mx/wb/Cofetel_2008/Cofe_televi sion_restringida_19922007_trimestral

16. Televison Restringia por Entidad Federativa . (2008). Retrieved December 5, 2009, from 
http://cofetel.gob.mx/wb/Cofetel_2008/Cofe_televisi on_restringida_por_entidad_federativ

17. Porcentage de Viviendas que Disponen de Television Octubre 2005. (2005). Retrieved March 30, 2009, from

http://www.cft.gob.mx/wb/Cofetel_2008/Cofe_porce ntaje_de_viviendas_particulares_habita 